\title{
The Effectiveness of Regional Regulation of The Province of Bali Number 16 of 2009 Concerning Spatial Planning for The Province of Bali in The Development of Tourism Supporting Facilities at The Sanctuary Area in Badung Regency
}

\author{
Ida Ayu Putu Widiati, Luh Putu Suryani and *Indah Permatasari \\ Faculty of Law, Universitas Warmadewa, Denpasar, Bali-Indonesia \\ *indah.permatasari5175@yahoo.com
}

Published: 28/02/2020

How to cite: Widiati, I. A. P., Suryani, L. P., \& Permatasari, I. 2020. The Effectiveness of Regional Regulation of The Province of Bali Number 16 of 2009 Concerning Spatial Planning for The Province of Bali in The Development of Tourism Supporting Facilities at The Sanctuary Area in Badung Regency. Sociological Jurisprudence Journal. 3(1). 54-58. https://doi.org/10.22225/ scj.3.1.1593.54-58

\begin{abstract}
One of the highly developed tourism industries in Bali is the tourism industry. Nevertheless, the problem that then arises is that there are developments encountered in the area of the holy place that should not be made as a place to support the tourism facilities. This is of course not in accordance with the provisions of Regional Regulation Number 16 of 2009 concerning Spatial Planning for the Province of Bali, particularly in Article 50 paragraph (2). This study examines the effectiveness of Bali Province Regional Regulation Number 16 of 2009 related to the construction of Tourism supporting facilities in the radius of the shrine area in Badung Regency. The whole data collected are processed and analyzed by organizing them systematically, and are then classified and connected between one data with another. In practice, there are still violations related to the rules of the radius of the sacred area around the Pura Sad Kahyangan, especially in the Pura Luhur Uluwatu. The existence of norms related to sacred areas comes through pros and cons in practice. Some judicial review requests have even been submitted to the Supreme Court. The role of law enforcement also needs necessarily to be optimized, especially in terms of enforcing the rule of law related to violations in the radius of the holy place in the Badung Regency.
\end{abstract}

Keywords: Tourism; Sanctuary Areas; Spatial Planning

\section{INTRODUCTION}

The development of the tourism industry, especially in the Province of Bali, of course can have negative impacts and can also bring positive impacts. The development of the tourism industry is of course inseparable from the role of the community, tourists, the Government, Local Government, and entrepreneurs. Thus, the positive impacts of the development of the tourism industry are certainly also experienced by tourism entrepreneurs who provide tourism facilities for tourists. Tourismentrepreneurs play a role in providing supporting facilities for the passage of tourism activities. Unfortunately, the problem that then arises is the existence of supporting facilities for tourism built in restricted areas, one of which is the area of the holy site.

The sanctuaries constitute areas around the temples whose sanctity needs to be maintained within a certain radius according to the status of the temple as stipulated in the Bhisama Purity of Temple (Bhisama Kesucian Pura) of Parisadha Hindu Dharma of Central Indonesia (Parisadha Hindu Dharma Indonesia Pusat or abbreaviated as PHDIP) of 1994. This is prescribed in the provision of Article 1 number 41 of the Regional Regulation of Bali Province, Number 16 of 2009 concerning Spatial Planning for the Province of Bali. Based on the provisions of Article 50 paragraph (2) of the Regional Regulation Number 16 of 2009 concerning the Spatial Planning for the Province of Bali, the sanctuary area is determined by referring to Bhisama of PHDIP of 1994, the criterion of which is serving as a sanctuary area around Pura Sad Kahyangan with a radius of at least the lack of apeneleng agung, a threshold - especially used by Balinese people to measure the extent to which we can see an object or 
The Effectiveness of Regional Regulation of The Province of Bali Number 16 of 2009 Concerning Spatial Planning for The Province of Bali in The Development of Tourism Supporting Facilities at The Sanctuary Area in Badung Regency

entity, is equivalent to 5,000 (five thousand) meters from the outer wall of the temple wall. Thus, it can be seen that at this radius it is not permissible to establish Tourism supporting facilities, especially in Badung Regency.

Pura Sad Kahyangan located in Badung Regency, which is stated in Regional Regulation Number 16 in 2019, is Pura Luhur Uluwatu (Bukit Pecatu in Badung Regency) and Pura Pucak Mangu (in Badung Regency). However, the object of this study is Pura Luhur Uluwatu, which is one of the tourist destinations in Badung Regency. Pura Luhur Uluwatu is one of the temples that have become a tourist attraction that has an attraction for tourists, both local and foreign tourists. This temple was also established in Bukit Pecatu in Badung Regency which is a tourist destination that is most sought after by tourists. The problem that then arises in connection with this is the detection of supporting tourism facilities, which are less than 5000 (five thousand) meters from Pura Luhur Uluwatu. The determination of this area has then been still often violated, both by the local community and investors to support its tourism business activities in the Province of Bali (Dewi \& Sarjana, 2018). Thus, a violation of Article 50 paragraph (2) of Regional Regulation Number 16 of 2009 concerning the Spatial Plan of the Province of Bali has taken place. Utilization of land that is still included in the radius of the sacred area may only be used for activities related to Hindu religious spiritual facilities, there are no permits to be used for purposes other than what has been determined, including being prohibited from building accommodation to support tourism (Wibawa, 2016). Based on matters as described above, the issues addressed in this study are the effectiveness of Regional Regulation number 16 of 2009 concerning Spatial Planning for the Province of Bali in the construction of Tourism supporting facilities in the sanctuary areas in Badung Regency and How is the reconstruction of legal norms to overcome violations in the construction of Tourism supporting facilities in the sanctuary areas in Badung Regency?

\section{METHOD}

This research is an empirical legal research. The data used are primary and secondary data. In this research the technique used to collect data is interview. This study makes use of a non-probability/nonrandom sampling technique, with a purposive sampling method. All data collected are processed and analyzed systematically.

\section{RESULT AND DISCUSSION}

\section{The Effectiveness of Regional Regulation Number 16 of 2009 concerning Spatial Planning for the Province of Bali in the Development of Tourism supporting facilities in the Sanctuary Area in Badung Regency}

Regional Regulation Number 16 of 2009 concerning Spatial Planning for the Province of Bali regulates about the area of sanctuaries. In the provision of Article 50 paragraph (2) of Regional Regulation, Number 16 Year 2009 regarding the Spatial Planning of the Province of Bali, the criteria for the sanctuary area have been determined, that is, the one which is determined by referring to the Bhisama PHDIP of 1994 which specifically regulates the sanctuary areas around Pura Sad Kahyangan. The radius of the shrine area in question is at least apeneleng agung equivalent to 5,000 (five thousand) meters from the outside of the temple wall. With regard to this sacred area, the Explanation of the Regional Regulation of Bali Province, Number 16 of 2009 concerning the Spatial Planning of the Province of Bali is also clarified, especially in the explanation of Article 44 paragraph (10) which specifies that the distribution of the location of the purity radius of the Pura Sad Kahyangan is based on the conceptions of Rwa Bhineda, Tri Guna, Catur Lokapala, Sad Winayaka/Padma Bhuana, specifically those located in Badung Regency, including: Pura Luhur Uluwatu and Pura Pucak Mangu. However, what is used as an object in this study is Pura Luhur Uluwatu in Badung Regency, which is one of the tourist destinations most frequently visited by local and foreign tourists. If the attachment of the Bali Province Regulation Number 16/2009 concerning the Distribution and Geographical Coverage of the Tourism Area and the Distribution of Tourist Attraction outside the tourist area is traced, there can be found several holy sites in the Bali spatial plan which are also designated as tourism areas (Sudiarta, 2011).

The existence of the article of the law relating to the area of these holy sites raises problems in practice. As a result, there are a number of people who submitted a petition for the review of Regional 
The Effectiveness of Regional Regulation of The Province of Bali Number 16 of 2009 Concerning Spatial Planning for The Province of Bali in The Development of Tourism Supporting Facilities at The Sanctuary Area in Badung Regency

Regulation Number 16 of 2009 concerning the Bali Provincial Spatial Plan for the law. The Supreme Court Decision related to the judicial review consists of the Supreme Court Decision Number 30 P/ HUM/2010, the Supreme Court Decision Number 32 P/HUM/2010, and the Supreme Court Decision Number $65 \mathrm{P} / \mathrm{HUM} / 2013$. The reasons for the petitioners in the Decision are that in general landowners living in the sanctuary area cannot take advantages of their lands, especially for business activities or the provision of tourism infrastructure. Landowners, of course, cannot utilize their land to be made use of because it is affected by the radius of the Pura Luhur Uluwatu shrine area equivalent to 5,000 (five thousand) meters.

The the collection of the data of the study was carried out through interviews with several agencies namely the Public Works and Spatial Planning Office of Badung Regency, and Public Order Enforcers (or Indonesian people abbreviate it as SATPOL PP) of Badung Regency. With regard to this, the actual existence of the rule of law governing the sanctuary area is a significant rule to apply. In addition to being regulated in the Regional Regulation of the Province of Bali Number 16 of 2009 concerning Spatial Planning of the Province of Bali, the existence of legal rules related to the regulation of the sanctuary area is also set forth in the Regional Regulation of Badung Regency Number 26 of 2013 concerning the Spatial Planning of the Badung Regency. There are several article provisions governing the sanctity of shrines in Regional Regulation Number 26 of 2013 concerning Spatial Planning of the Regency of Badung, namely the provisions of Article 1, number 32, which states that the Sanctuary Area is an Area in the area around the temple whose sanctity needs to be maintained within a certain radius according to the status of the temple, as stipulated in the Pura Bhisama Pura Parisadha Hindu Dharma of Center Indonesia (PHDIP) of 1994. The area of the shrine is classified as a local protected area regulated in the provisions of Article 25 of the Regional Regulation of Badung Regency Number 26 of 2013 concerning the Planning Regional Space of Badung Regency, which determines that the local protected area consists of: Sacred Area; Sanctuary Area; Beach Border Area; River Border Area; Reservoir border area/estuary dam; and the Abyss border area.

The legal rules governing the sanctuary areas are also regulated in Article 27 of the Regional Regulation of Badung Regency, Number 26 of 2013 concerning Spatial Planning of the Area of Badung Regency which determines that the Sanctuary Area consists of: Purity Radius Area of Pura Sad Kahyangan, Pura Dang Kahyangan, Pura Jagatangan Jagat and Purity Area of Pura Kahyangan Tiga and other temples. The area of Pura Sad Kahyangan sanctity radius includes: Puncak Mangu Pura Area in Pelaga Village, Petang District and Pura Luhur Uluwatu Area in Pecatu Village, South Kuta Subdistrict. Other legal basis governing the area of shrines, especially those in Badung Regency is the Regional Regulation of Badung Regency, Number 7 of 2018 concerning Detailed Spatial Plan and Zoning Regulations of the Subdistrict of South Kuta. In this regional regulation, the sanctuary area belongs to the local protection zone regulated in the provisions of Article 13. Further provisions relating to the sanctuary area are also regulated in the provisions of Article 64 of Regional Regulation of Badung Regency, Number 7 of 2018 on Detailed Spatial Plan and Zoning Regulation of South Kuta Subdistrict. Based on the three legal rules, indeed there are clear rules relating to the area of the sacred sites, especially in Badung Regency. The three rules of law explicitly regulate the area of the sacred sites around Pura Sad Kahyangan with a radius of at least the apeneleng agung which is equivalent to 5,000 (five thousand) meters from the outer side of the temple wall. However, in practice violations related to this rule are still encountered.

Pura Luhur Uluwatu region is one of the tourist destinations visited by many tourists, both local and foreign tourists. So, this area serves as one of the areas included in the category of tourism industry. However, problems then arise due to the discovery of supporting tourism facilities in this area. In fact, it has clearly been regulated that there is a radius of at least the apeneleng agung which is equivalent to 5,000 (five thousand) meters from the outer side of the temple wall. The enactment of Article 50 paragraph (2) of Regional Regulation Number 16 of 2009 concerning the Regional Spatial Plan of the Province of Bali concerning the area of the holy sites has not been effective. This is caused by the performance control of spatial use that is still not optimal, so that the impact is on the existence of buildings and Tourism supporting facilities that are built in areas and that are prohibited according to legal provisions. Discussions on this matter are also crucial to be carried out by the government as policy makers, the community, and local community leaders. This is due to the fact that there are still disadvantaged communities with the existence of this rule which is guaranteed in the Supreme Court 
The Effectiveness of Regional Regulation of The Province of Bali Number 16 of 2009 Concerning Spatial Planning for The Province of Bali in The Development of Tourism Supporting Facilities at The Sanctuary Area in Badung Regency

Decree Number 30/P/HUM/2010, Supreme Court Decision Number 32/P/HUM/2010, and the Supreme Court Decision Number $65 / \mathrm{P} / \mathrm{HUM} / 2013$. In this decision, it can be seen that the reason for the petitioner is that he as the owner of the land in the area of the sacred sites does not benefit from his own land, especially for use as a business activity to provide tourism supporting facilities and infrastructure.

In essence, the existence of Article 50 paragraph (2) of Regional Regulation Number 16 of 2009 concerning Spatial Planning of the Province of Bali is hitting the mark. This is because the existence of the article is related to the area of the sacred sites which in essence protects the sanctity of the temple. Unfortunately, the problem that arises is that there are still many buildings that are found in the radius of the sanctuary area, especially in Pura Luhur Uluwatu. This problem also began to rise in advance of the Regional Regulation Number 16 of 2009 concerning Spatial Planning of the Province of Bali; since then the building has been built around the temple area. This is one of the fundamental problems and has occurred. In addition to this, the land in this area also has a high value. This is due to the fact that this area is classified as an area known for its tourism industry which of course is attractive for tourism entrepreneurs to establish Tourism supporting facilities such as hotels, restaurants and villas.

\section{Reconstruction of Legal Norms to Overcome Violations in the Development of Tourism supporting facilities in the Sanctuary Area in Badung Regency}

The sanctuary area is the area around the temple whose sanctity needs to be preserved within a certain radius according to the status of the temple as stipulated in the Bhadama Pura Purity Parisadha Hindu Dharma of Centre Indonesia (PHDIP) of 1994. There are several legal rules governing the area of the sacred sites, especially in Badung Regency. The legal rules in question are Regional Regulation Number 16 of 2009 concerning Spatial Planning of the Province of Bali, Regional Regulation of Badung Regency Number 26 of 2013 concerning Spatial Planning of Badung Regency and Regional Regulation of Badung Regency Number 7 of 2018 Detailed Spatial Plan and Zoning Regulation of South Kuta Subdistrict.

The existence of norms related to the sanctuary area also experiences pros and cons in practice. There are several requests for judicial review submitted to the Supreme Court related to the existence of Article in Regional Regulation, Number 16 of 2009 concerning Spatial Planning of the Province of Bali. This is because there are still residents who are disadvantaged by the existence of this rule which is reflected in the Supreme Court Decision Number 30/P/HUM/2010, Supreme Court Decision Number 32/P/HUM/2010, and Supreme Court Decision Number 65/P/HUM/2013 (Atmaja, Aryani, Utari, \& Griadhi, 2017). In the decisions it is found that the reason of the petitioners was that those who owned the land in the area of the sacred sites could not use their land, especially for business activities of providing tourism supporting facilities and infrastructure.

In the three decisions, Decision of the Supreme Court Number 30/P/HUM/2010, Decision of the Supreme Court Number 32/P/HUM/2010, and Decision of the Supreme Court Number 65/P/HUM/2013, the Supreme Court considered that Regional Regulation Number 16 The 2009 Spatial Plan of the Province of Bali is not in conflict with the higher laws, namely Law Number 12 of 2011 concerning the Formation of Laws and Regulations Number 32 of 2004 concerning Regional Government, as well as Laws Law Number 26 of 2007 concerning Spatial Planning. Therefore, the article in Regional Regulation Number 16 of 2009 concerning the Spatial Planning of the Province of Bali that is reviewed judicially still applies.

The sanctuary is categorized as a local protected area. The list of permitted or prohibited activities and utilization of space is regulated in Attachment XIX of Regional Regulation of Badung Regency Number 7 of 2018 of Detailed Spatial Plan and Zoning Regulation of South Kuta Subdistrict. In the provisions contained in Attachment XIX of Regional Regulation of Badung Regency, Number 7 of 2018 of the Detailed Spatial Plan and Zoning of the said Regulations of South Kuta Subdistrict, which buildings are permitted and prohibited in the sanctuary area are clearly detailed. Based on the provisions in Attachment XIX of the Regional Regulation of Badung Regency, Number 7 of 2018 of the Detailed Spatial Plan and Zoning Regulation of South Kuta Subdistrict it can be seen that the local protection zone (abbreviated as $P S)$, i.e., the sanctuary sub-zone (PS-2) may not be used as a place for tourism supporting buildings such as hotels, villas and restaurants. This provision is clearly stated in Attachment XIX of the Regional Regulation of the Badung Regency, Number 7 of 2018 of the Detailed Spatial Plan 
and Zoning Regulation of the Subdistrict of South Kuta. Unfortunately, in practice violations related to this matter are still encountered. Apparently in the provision of Article 100 of the Regional Regulation of Badung Regency Number 26 of 2013 concerning Spatial Planning of the Regency of Badung, the rule of law related to sanctions for everyone who commits violations in the spatial planning field has been stipulated. The direction of sanctions regulated in Article 100 is in the form of administrative sanctions and criminal sanctions. Sanctions are imposed not only on everyone who commits violations in the field of Spatial Planning but also are imposed to authorized officials who grant permits. Legal reconstruction involving the community, the government as policy makers, academics and community leaders to produce a law that is able to be obeyed is also important to form.

\section{CONCLUSION}

Legal regulations regarding to sacred areas, especially in Badung Regency, are regulated in Regional Regulation Number 16 of 2009 concerning Regional Spatial Planning of the Province of Bali. However, in practice it was found that there were still violations related to the rules of the radius of the sanctuaries around Pura Sad Kahyangan with a radius of at least apeneleng agung, a threshold - especially used by Balinese people to measure the extent to which we can see an object or entity, equivalent to 5,000 (five thousand) meters from the outer side of the temple wall. Legal reconstruction can be done by involving the community, the government as policy makers, academics and community leaders to produce laws that have the power to urge every citizen to obey related to the determination of the radius of the shrine area in Badung Regency.

\section{REFERENCES}

Atmaja, G. M. W., Aryani, N. M., Utari, A. A. S., \& Griadhi, N. M. A. Y. ni. (2017). Pluralisme Konstitusional dalam Pengakuan Kesatuan Masyarakat Hukum Adat. Retrieved from https://books.google.co.id/books? id=xi1LDwAAQBAJ

Bali Province Regional Regulation Number 16 of 2009 related to the construction of Tourism supporting facilities

Dewi, I. A. P. T., \& Sarjana, I. M. (2018). Analisis Yuridis Penetapan Kawasan Tempat Suci Dalam Penataan Ruang di Provinsi Bali. Kertha Negaran Journal Ilmu Hukum, 6(3), 1-15. Retrieved from https:// ojs.unud.ac.id/index.php/Kerthanegara/article/view/40984

Regional Regulation Number 16 of 2009 concerning Spatial Planning for the Province of Bali

Sudiarta, I. K. (2011). Penetapan Kawasan Tempat Suci dan Kawasan Pariwisata Dalam Penataan Ruang di Bali. Masalah-Masalah Hukum, 40(1), 66-72. Retrieved from https://ejournal.undip.ac.id/index.php/mmh/article/ view/13056

Wibawa, I. P. S. (2016). Rekonstruksi Hukum Tata Ruang Kawasan Tempat Suci di Bali Berbasis Kearifan Lokal dan Pancasila. Law Research Review Quarterly, 2(1). Retrieved from http://garuda.ristekbrin.go.id/ documents/detail/826804 